\author{
UNIVERSITY OF CALIFORNIA \\ COLLEGE OF AGRICULTURE \\ AGRICULTURAL EXPERIMENT STATION \\ BERKELEY, CALIFORNIA
}

\title{
COST OF WORK HORSES ON CALIFORNIA FARMS
}

R. L. ADAMS

\section{BULLETIN 401}

APRIL, 1926 
Digitized by the Internet Archive in 2012 with funding from University of California, Davis Libraries 


\title{
COST OF WORK HORSES ON CALIFORNIA FARMS
}

\author{
R. L. ADAMS
}

California farmers continue to rely upon horses and mules as a source of motive power, although increasing use of tractors and trucks is tending to replace horse-power with mechanical power. The number of horses and mules, of all ages, on California farms and ranges, was reported by the 1920 Federal Census as 456,826 on January 1, 1920. By January 1, 1923, the total number was estimated at 401,000.*

A year later a drop of 16,000 was recorded, lowering the total to 385,000 . On January 1, 1925, a further drop of 6000 was reported, thus further lowering the total number of horses and mules to 379,000 .

\section{STUDIES OF COSTS OF HORSE LABOR BY THE DIVISION OF FARM MANAGEMENT}

Notwithstanding the gradual reduction in numbers of horses and mules, the annual cost of horse and mule power reaches a high figure. Considerable quantities of data have been collected by the Division of Farm Management, which appear to be worthy of recording for use by farm managers and agricultural economists who are concerned with plans of farm organization, details of farm administration, and costs of production studies.

The data were collected by trained investigators, who visited each of the selected farms, and there filled in specially prepared blanks upon which were recorded pertinent data as to numbers of work animals, values, rates of depreciation and mortality, methods of handling, cost items, and inventories of buildings and equipment used in connection with the work horses. Book records were seldom available so that much of the data had to be drawn from farmers' estimates. All items were carefully considered, detail by detail, both by the investigator and in making the office calculations. Only complete records taken from farmers with sufficient experience to render their judgment above reasonable doubt were retained. The survey method of collecting the records was used, and a sufficient number collected to safeguard the accuracy of the findings.

* This and the following figures of horse population are from The Coöperative Crop Reporting Service. 


\section{TYPES OF FARMING REPRESENTED BY RECORDS}

These data are from the records of 187 California farms. One hundred forty records are from ranches primarily devoted to the production of field crops and dairying: The other 47 from farms specializing in deciduous fruit production. The farms from which the records were obtained are typical of the farming practices and equipment in the districts where they were taken. The dairy and field crops records were gathered in twenty counties. The majority were obtained: Nine from Del Norte and Humboldt counties; 15 from Marin and Sonoma counties ; 20 from Alameda, Contra Costa, Santa Clara and San Benito counties; 35 from Sacramento and Yolo counties; 32 from San Joaquin, Fresno, Kings, and Kern counties; 24 from Los Angeles, Orange, San Bernardino, and San Diego counties. The 47 fruit farm records were taken: Ten in Santa Clara County, 8 from Santa Cruz County, 7 from Solano County, 9 from San Joaquin County, and 13 from Fresno County.

Collection of the records for the dairy and field crops ranches was completed by April 1, 1923; the records from the fruit farms were collected during July, 1923. All are based on the calendar year of 1922.

\section{ITEMS CONSTITUTING COSTS OF HORSE LABOR}

Annual cost of horse labor is a composite of a number of items. The most important are direct expenditures for feed and care, and indirect costs of depreciation and mortality and of interest upon the investment in horses. Incidental items include taxes, occasionally insurance and the cost of shelter and equipment.

The following table shows a commonly accepted basis for calculating horse labor costs :

Table of Items Entering Into the Calculations of Horse Labor Costs

Operating Costs of Horses:

Feed (hay, grain, pasture, etc.)

Bedding

Chores (feeding, grooming, cleaning, stables, supervising when on pasture, pumping water, etc.)

Shoeing

Veterinary services

Taxes

Insurance 
Overhead Costs of Horses:

Interest on investment in horses

Depreciation of horses

Mortality of horses
Cost of Shelter Utilized by Horses:

Interest on investment

Depreciation

Upkeep

Taxes

Insurance

Cost of Equipment Used by Horses (harness, curry combs, brushes, barn forks, shovels, etc.):

Interest on investment

Depreciation

Repairs

Taxes

Insurance

The total of these items gives gross cost. Net cost is determined by deducting from the gross cost credits for outside work, for manure, and for value of colts raised to weaning age. The colt values are taken at the net value, found by deducting from the market value all costs of breeding, care, and rearing to weaning age.

Net cost-the figure sought-can be expressed in dollars per year, dollars and cents per work day, or cents per work hour.

\section{METHOD OF FIGURING ITEMS OF COST}

To obtain basic data, feeds were worked out in accordance with the kinds used, length of the feeding periods, and costs of feeds at current farm prices. If bought and hauled, farm prices consisted of the purchase price plus hauling cost. If farm-raised, the value was figured at market price less cost of preparing, delivering, and selling at a point where market price could be obtained.

Very little bedding was used, other than waste hay from the mangers. If straw or other bedding was used, a charge was figured in the same way as for the feed costs.

The cost of chores was found by multiplying the average time required per year by the "going" rate of wages. The going rate of wages included cash wages and the value of board, housing and other perquisites.

Shoeing, veterinary services, taxes, and insurance are totals of amounts actually expended.

The overhead costs of horses are here made up of interest at 6 per cent on the current investment or value of the horses studied; Depreciation, determined by dividing the value of the horses when at the peak of their usefulness by the estimated years of profitable life; and mortality figured in accordance with the operators' experience. 
The charge for shelter is based on the quarters actually used by the horses. It is made up of interest at 6 per cent on the current investment, depreciation (found by dividing the initial cost of the structure by the number of years of probable life); upkeep (the average annual outlay for repairs, painting, and similar charges), taxes, and insurance.

The charge for equipment used by the horse department is figured similarly to that employed in determining the charge for shelter.

\section{FINDINGS}

Cost data were collected for 812 work horses on the 187 California farms studied. Six hundred sixty-five head were on 140 dairy and field crops farms, ranging in number per farm from 1 to 31 head and averaging 4.3 per farm. One hundred forty-seven were on 47 orchard and vineyard farms, ranging in numbers per farm from 1 to 12 head and averaging 3.1 per farm. The classification by numbers per farm is set forth in the following table:

TABLE 1

Classification Showing Number of Work Horses Per Farm

\begin{tabular}{c|c|c}
\hline \multirow{2}{*}{ Number of horses per farm } & \multicolumn{2}{|c}{ Farms grouped according to number of horses } \\
\cline { 2 - 3 } & Dairy and field crops group & Orchard and vineyard group \\
\cline { 2 - 3 } 1 & 6 & 2 \\
2 & 35 & 25 \\
3 & 19 & 5 \\
4 & 36 & 10 \\
5 & 14 & 1 \\
6 & 7 & 1 \\
7 & 2 & $\ldots$ \\
8 & 7 & 1 \\
9 & 1 & 1 \\
10 & 2 & $\ldots$ \\
11 & 2 & $\ldots$ \\
12 & 5 & $\ldots$ \\
16 & 2 & $\ldots$. \\
26 & 1 & $\ldots$ \\
31 & 1 & 47 \\
& 140 & \\
\end{tabular}

The majority of farms in both groups were equipped with two, three, or four horses each, with the data indicating a tendency toward either two or four horses. 
Feed.

Various combinations of feeds were used. The majority of operators fed nothing but hay or hay and pasture. The findings are set forth in table 2.

TABLE 2

Clasification of Feeding Methods

\begin{tabular}{|c|c|c|c|c|c|c|c|c|c|}
\hline \multirow[b]{2}{*}{ Feeding method } & \multicolumn{3}{|c|}{$\begin{array}{l}\text { Dairy and field crops } \\
\text { group }\end{array}$} & \multicolumn{3}{|c|}{$\begin{array}{l}\text { Orchard and vineyard } \\
\text { group }\end{array}$} & \multicolumn{3}{|c|}{ All farms } \\
\hline & $\begin{array}{c}\text { Per } \\
\text { cent of } \\
\text { farms } \\
\text { in } \\
\text { group }\end{array}$ & \begin{tabular}{|c} 
Per \\
cent of \\
horses \\
in \\
group
\end{tabular} & $\begin{array}{c}\text { Num- } \\
\text { ber of } \\
\text { hours of } \\
\text { work } \\
\text { per } \\
\text { horse }\end{array}$ & $\begin{array}{c}\text { Per } \\
\text { cent of } \\
\text { farms } \\
\text { in } \\
\text { group }\end{array}$ & $\begin{array}{l}\text { Per } \\
\text { cent of } \\
\text { horses } \\
\text { in } \\
\text { group }\end{array}$ & $\begin{array}{c}\text { Num- } \\
\text { ber of } \\
\text { hours of } \\
\text { work } \\
\text { per } \\
\text { horse }\end{array}$ & $\begin{array}{c}\text { Per } \\
\text { cent of } \\
\text { farms }\end{array}$ & $\begin{array}{l}\text { Per } \\
\text { cent of } \\
\text { horses }\end{array}$ & $\begin{array}{l}\text { Num- } \\
\text { ber of } \\
\text { hours of } \\
\text { work } \\
\text { per } \\
\text { horse }\end{array}$ \\
\hline Hay only.... & 33 & 25 & 1574 & 25 & 16 & 1256 & 31 & 23 & 1535 \\
\hline Hay and pasture. & 31 & 31 & 1487 & 6 & 7 & 1767 & 25 & 27 & 148.3 \\
\hline Hay and grain... & 21 & 22 & 2130 & 38 & 37 & 1237 & 25 & 25 & 1889 \\
\hline $\begin{array}{c}\text { Hay, grain, and } \\
\text { pasture.................... }\end{array}$ & 15 & 22 & 1639 & 30 & 40 & 1386 & 19 & 25 & 1467 \\
\hline
\end{tabular}

Amounts fed varied with different operators and in different localities, the methods depending somewhat on available pasture, proportion of purchased feeds, current costs, and amount of heavy work required of the teams. The table gives an idea of feeding practice.

TABLE 3

Average Amounts of Feeds Used Per Horse fer Year

\begin{tabular}{|c|c|c|c|}
\hline Kind and amount of feed & $\begin{array}{l}\text { Dairy and } \\
\text { field crops } \\
\text { group }\end{array}$ & $\begin{array}{l}\text { Orchard and } \\
\text { vineyard } \\
\text { group }\end{array}$ & All farms \\
\hline Нау............ & 6 tons & 6 tons & 6 tons \\
\hline Наy..... & 5.4 tons & 6.8 tons & 5.9 tons \\
\hline Grain $\ldots \ldots . .$. & $903 \mathrm{lbs}$. & 577 lbs. & $780 \mathrm{lbs}$ \\
\hline Hay................ & 4.3 tons & 4.3 tons & 4.3 tons \\
\hline Pasture & $5.1 \mathrm{mos}$. & $4.3 \mathrm{mos}$ & 5 mos. \\
\hline Hay... & 3.6 tons & 5.9 tons & 4.5 tons \\
\hline Grain...... . & $631 \mathrm{lbs}$. & 717 lbs. & $666 \mathrm{lbs}$. \\
\hline Pasture..... & $6.1 \mathrm{mos}$ & $3.8 \mathrm{mos}$. & $5.2 \mathrm{mos}$. \\
\hline
\end{tabular}

All methods of feeding considered, horses used on orchard and vineyard farms were fed more hay, more grain, and less pasture than those on dairy and field crop farms, probably owing to less available pasturage. The weighted averages per head per year are: 


\begin{tabular}{|c|c|c|}
\hline & $\begin{array}{l}\text { Dairy and field crop } \\
\text { group }\end{array}$ & $\begin{array}{c}\text { Orchard and vineyard } \\
\text { group }\end{array}$ \\
\hline Нау.... & \multirow{3}{*}{$\begin{array}{l}5.0 \text { tons } \\
274 \mathrm{lbs} \text {. } \\
2.5 \text { mos. }\end{array}$} & \multirow{3}{*}{$\begin{array}{l}6.0 \text { tons } \\
435 \mathrm{lbs} . \\
1.5 \mathrm{mos} .\end{array}$} \\
\hline Grain .... & & \\
\hline Pasture & & \\
\hline
\end{tabular}

Cost of feed per head per year based on current prices for the period under study (1922) was found to be as follows:

\begin{tabular}{|c|c|c|c|}
\hline & $\begin{array}{l}\text { Dairy and } \\
\text { field crops } \\
\text { group }\end{array}$ & $\begin{array}{l}\text { Orchard and } \\
\text { vineyard } \\
\text { group }\end{array}$ & All farms \\
\hline $\begin{array}{l}\text { Range in costs: } \\
\text { High. } \\
\text { Low } \\
\text { Average } \\
\text { Frequency (in percentages of total number } \\
\text { of farms): } \\
\text { Less than } \$ 50 \\
\$ 50 \text { to } \$ 75 \\
\$ 75 \text { to } \$ 100 \\
\$ 100 \text { to } \$ 125 \\
\text { Over } \$ 125\end{array}$ & $\begin{array}{r}\$ 295.00 \\
23.82 \\
89.80\end{array}$ & $\begin{array}{c}4 \% \\
39 \\
28 \\
29\end{array}$ & $\begin{array}{l}7 \% \\
17 \\
33 \\
22 \\
21\end{array}$ \\
\hline
\end{tabular}

The average for all horses per head per year amounted to $\$ 95.75$.

Feed costs for the period were as follows:

\begin{tabular}{|c|c|c|}
\hline & $\begin{array}{l}\text { Dairy and field crops } \\
\text { group }\end{array}$ & $\begin{array}{c}\text { Orchard and vineyard } \\
\text { group }\end{array}$ \\
\hline Pasture, per horse per month: & \multirow{5}{*}{$\begin{array}{l}\$ .50-\$ 5.25 \\
2.50 \\
2.50\end{array}$} & \multirow{4}{*}{$\begin{array}{l}\$ 2.00-\$ 6.00 \\
4.00 \\
3.00\end{array}$} \\
\hline Range........................ & & \\
\hline Average............... & & \\
\hline Mostly....... & & \\
\hline Hay, per ton: & & \multirow{4}{*}{$\begin{array}{l}\$ 12.00-\$ 25.00 \\
17.50 \\
18.00\end{array}$} \\
\hline Range.......... & \multirow{3}{*}{$\begin{array}{l}\$ 8.50-\$ 28.00 \\
15.75 \\
15.00\end{array}$} & \\
\hline Average....... & & \\
\hline Mostly............... & & \\
\hline Grain, per cwt.: & \multirow{4}{*}{$\begin{array}{l}\$ 1.15-\$ 3.05 \\
1.75 \\
1.75\end{array}$} & \multirow{4}{*}{$\begin{array}{l}\$ 1.25-\$ 2.62 \\
2.00 \\
1.75\end{array}$} \\
\hline Range................ & & \\
\hline Average........... & & \\
\hline Mostly....... & & \\
\hline
\end{tabular}


Costs of feeds vary within wide limits, being influenced by kinds and amounts of feeds grown in the locality, by demand, quality, and possible markets, and by costs of preparing for market, of transport and of selling.

The average cost of feeds per head per year was found to be:

\section{TABLE 4}

Average Cost of Feeds Per Head Per Year

\begin{tabular}{|c|c|c|c|c|}
\hline & \multicolumn{2}{|c|}{ Dairy and field crops group } & \multicolumn{2}{|c|}{ Orchard and vineyard group } \\
\hline & Amount & Cost & Amount & Cost \\
\hline \multirow{4}{*}{ 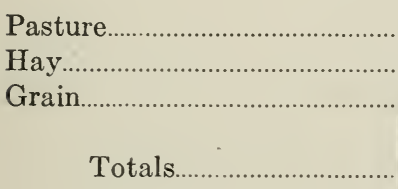 } & $2.5 \mathrm{mos}$. & $\$ 6.25$ & $1.5 \mathrm{mos}$. & $\$ 6.00$ \\
\hline & 5 tons & 78.75 & 6 tons & 105.00 \\
\hline & $274 \mathrm{lbs}$ & 4.80 & $435 \mathrm{lbs}$. & 7.61 \\
\hline & & $\$ 89.80$ & & $\$ 118.61$ \\
\hline
\end{tabular}

Chores.

Time required for chores is variable. On the 187 farms, the time required per horse per day varied from only a few minutes to one hour.

Classified, the records showed:

TABLE 5

Time Spent in Chores Per Horse Per Day

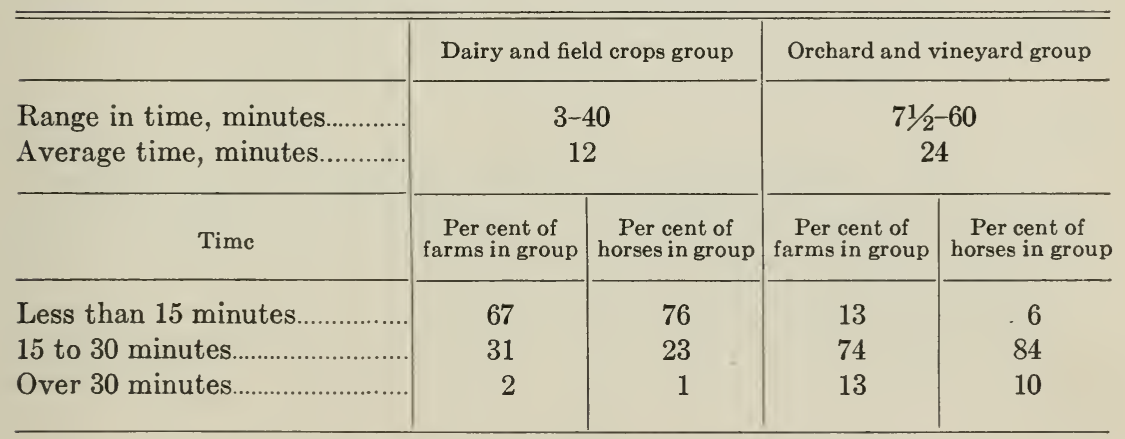

The average time spent in chores for all farms averaged 15 minutes per horse per day.

The rate per hour for time spent in chores ranged from 18 cents to $461 / 2$ cents, with an average rate of 30.9 cents. The majority of operators paid from 25 to 30 cents per hour. An idea of the range in wages paid by the different operators can be gained from table 6 . 
TABLE 6

Rate of Wages PaId For Chores

\begin{tabular}{|c|c|c|c|}
\hline Rate per hour & $\begin{array}{l}\text { Dairy and field crops } \\
\text { group }\end{array}$ & $\begin{array}{l}\text { Orchard and vineyard } \\
\text { group }\end{array}$ & All farms \\
\hline $\begin{array}{c}\text { Cents } \\
18-25 \ldots \ldots \ldots \ldots \ldots \\
26-30 \ldots \ldots \ldots \ldots \ldots \ldots \ldots \ldots \\
31-35 \ldots \ldots \ldots \ldots \ldots \ldots \ldots \\
36-46.5\end{array}$ & $\begin{array}{c}\text { Percentage } \\
10 \\
42 \\
31 \\
17\end{array}$ & $\begin{array}{c}\text { Percentage } \\
28 \\
24 \\
7 \\
41\end{array}$ & $\begin{array}{c}\text { Percentage } \\
15 \\
37 \\
24 \\
24\end{array}$ \\
\hline Average rate... & $30.2 \mathrm{c}$ & $32.9 \mathrm{c}$ & $30.9 \mathrm{c}$ \\
\hline
\end{tabular}

The annual cost per horse for chores is determined by the amount of time spent in caring for the horses and the rate of wages. The average cost for the dairy and field crops group amounted $\$ 22.50$ per horse per year; for the orchard and vineyard group, $\$ 43.55$; and for all farms, $\$ 27.80$. The annual cost for the orchard and vineyard group is relatively high because of more chore work incident to keeping the horses regularly in barns and corrals and because of the somewhat higher wage rate, although the extra work is the major reason for the higher annual cost per horse per year.

The range in costs per horse per year for chores varied in the dairy and field crops farms from a minimum of $\$ 3.75$ to a maximum of $\$ 97.33$, the cost on the majority of farms being under $\$ 25$. The range for the orchard and vineyard farms was from $\$ 15.46$ to $\$ 146$, the cost on the majority of farms being between $\$ 20$ and $\$ 50$.

\section{Taxes.}

The amount of taxes paid was obtained from the county records or from the operators' tax statements. Valuations and tax rates varied in different counties and on different farms of the same county so that considerable range exists in the tax rate.

The range and averages paid per horse per year are here shown:

\section{TABLE 7}

Taxes PaId on Work Horses Pẹr Head PER Year

\begin{tabular}{|c|c|c|}
\hline & Range & Average \\
\hline Dairy and field crops group.... & $0-\$ 3.69$ & $\$ 1.42$ \\
\hline Orchard and vineyard group. & $\$ .80-6.00$ & 2.21 \\
\hline All farms... & $0-6.00$ & 1. 62 \\
\hline
\end{tabular}




\section{Value of Horses.}

The ranges in values placed upon workhorses are set forth in table 8 .

\section{TABLE 8}

Values of Work Horses per Head-Average for Year

\begin{tabular}{|c|c|c|c|}
\hline & Range & Average & Usual \\
\hline Dairy and field crops group.... & $\$ 38.33-\$ 233.33$ & $\$ 111.94$ & $\$ 100-\$ 150$ \\
\hline Orchard and vineyard group... & $37.50-200.00$ & 102.79 & $100-150$ \\
\hline All farms....... & $37.50-233.33$ & 107.33 & $100-150$ \\
\hline
\end{tabular}

The average annual interest charge per head at 6 per cent amounts to :

Dairy and field crops farms. $\$ 6.72$

Orchard and vineyard farms.

All farms.

\section{Mortality.}

The death rate as a factor in estimating costs of horse labor was discounted by practically one-fourth of the 187 operators who supplied data, in the belief that mortality was not sufficiently important to include. This was particularly true of men having but one, two, or three head of work horses, and in the orchard and vineyard group.

TABLE 9

Operators' Estimates of Work Horse Mortality

\begin{tabular}{|c|c|c|c|}
\hline $\begin{array}{l}\text { Rate of mortality } \\
\text { per year, per cent }\end{array}$ & $\begin{array}{l}\text { Classification of reports } \\
\text { in dairy and field crops } \\
\text { group }\end{array}$ & $\begin{array}{l}\text { Classification of reports } \\
\text { in orchard and vineyard } \\
\text { group }\end{array}$ & Total-all farms \\
\hline 0 & 1 & 45 & 46 \\
\hline 2 & 18 & & 18 \\
\hline 3 & 11 & 1 & 12 \\
\hline 4 & 2 & & 2 \\
\hline 5 & 77 & & 77 \\
\hline 6 & 3 & & 3 \\
\hline 7 & 6 & & 6 \\
\hline 8 & 6 & & 6 \\
\hline 10 & 13 & & 13 \\
\hline 15 & 2 & 1 & 3 \\
\hline \multirow[t]{2}{*}{16} & 1 & & 1 \\
\hline & 140 & 47 & 187 \\
\hline
\end{tabular}


Mortality is thus estimated by operators as ranging from 0 to $16 \%$, with an average mortality of $6.6 \%$ for the dairy and field crops group and only a nominal rate for the orchard and vineyard group. The average amounted to $5.1 \%$ or at the rate of approximately one horse in twenty per year.

Measured in Money, Mortality Per Head, Average

Dairy and field crops farms.

$\$ 7.39$

Orchard and vineyard farms

Nominal

All farms

$\$ 5.47$

\section{Depreciation.}

The productive life of a work horse was variously estimated by operators. Table 10 contains the various estimates grouped according to type of farming and varying ideas of profitable life.

TABLE 10

Details of Findings Concerning Depreciation of Horses

\begin{tabular}{|c|c|c|c|}
\hline $\begin{array}{c}\text { Estimated useful life per } \\
\text { horse }\end{array}$ & $\begin{array}{l}\text { Dairy and field crop } \\
\text { group }\end{array}$ & $\begin{array}{c}\text { Orchard and vineyard } \\
\text { group }\end{array}$ & All farms \\
\hline 20 years.. & 5 & 6 & 11 \\
\hline 16 years....... & 17 & 24 & 41 \\
\hline 14 years....... & 20 & 5 & 25 \\
\hline $121 / 2$ years.. & 48 & 7 & 55 \\
\hline 10 years......... & 41 & 4 & 45 \\
\hline 9 years.... & 1 & $\ldots$ & 1 \\
\hline 8 years.............. & 7 & 1 & 8 \\
\hline \multirow[t]{2}{*}{ 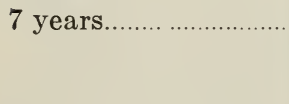 } & 1 & $\ldots$ & 1 \\
\hline & 140 & 47 & 187 \\
\hline
\end{tabular}

According to these estimates the useful life of a horse generally lies between 10 and 16 years, with a general average depreciation taken from all records as follows:

\begin{tabular}{|c|c|c|}
\hline & $\begin{array}{l}\text { Average depreciation } \\
\text { in percentage }\end{array}$ & $\begin{array}{l}\text { Average depreciation } \\
\text { in dollars }\end{array}$ \\
\hline Dairy and field crop farms. & \multirow{2}{*}{$\begin{array}{l}8.48 \% \\
7.01 \%\end{array}$} & \multirow{2}{*}{$\begin{array}{r}\$ 12.30 \\
13.13\end{array}$} \\
\hline Orchard and vineyard farms.... & & \\
\hline Weighted average for all farms. & $8.14 \%$ & $\$ 12.92$ \\
\hline
\end{tabular}




\section{Cost of Shelter.}

A charge for barn space occupied by horses, storage of hay for their use, and protection of harness is made up of interest on investment, depreciation, upkeep, taxes, and insurance. The cost per horse was as follows:

TABLE 11

Annual Charge of Shelter Per Animal

\begin{tabular}{|c|c|c|}
\hline & $\begin{array}{c}\text { Dairy and field crops } \\
\text { farms }\end{array}$ & $\begin{array}{c}\text { Orchard and vineyard } \\
\text { farms }\end{array}$ \\
\hline Range in charges: & \multirow{4}{*}{$\begin{array}{r}\$ 84.80 \\
.55 \\
11.27\end{array}$} & \multirow{4}{*}{$\begin{array}{r}\$ 36.30 \\
4.50 \\
17.25\end{array}$} \\
\hline 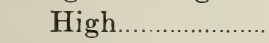 & & \\
\hline Low..................... & & \\
\hline Average..... & & \\
\hline Usual charge.... & $\$ 5-\$ 15$ & $\$ 20-\$ 30$ \\
\hline
\end{tabular}

The average shelter charge for all farms amounted to $\$ 12.77$ per animal per year.

\section{Charge for Equipment.}

The charge for use of equipment, such as harness, collars, halters, currycombs, brushes, barn brooms, shovels, pitch forks, and similar equipment is made up of interest upon investment, depreciation, upkeep, taxes, and insurance. The findings are set forth in the following table:

TABLE 12

Annual Charge for Use of Equipment per Animal

\begin{tabular}{|c|c|c|}
\hline & $\begin{array}{l}\text { Dairy and field crops } \\
\text { group }\end{array}$ & $\begin{array}{c}\text { Orchard and vineyard } \\
\text { group }\end{array}$ \\
\hline Range in charges: & \multirow{4}{*}{$\begin{array}{r}\$ 38.00 \\
1.14 \\
7.11\end{array}$} & \multirow{4}{*}{$\begin{array}{r}\$ 25.32 \\
1.17 \\
5.35\end{array}$} \\
\hline High... & & \\
\hline Low.... & & \\
\hline Average... & & \\
\hline Usual charges... & $\$ 2.00-\$ 10.00$ & $\$ 2.00-\$ 4.00$ \\
\hline
\end{tabular}

The average equipment charge for all farms amounted to $\$ 6.66$ per animal per year. 


\section{Miscellaneous.}

Miscellaneous charges consisted of shoeing, veterinary services and medicines. The cost per animal per year was not large. Of the 140 dairy and field crop farms, 32 reported no outlay for miscellaneous items and, similarly, 10 of the 47 orchard and vineyard group had no such expenditure.

The range and average for the two groups amounted to:

TABLE 13

Outlay per Animal per Year for Miscellaneous Expenditures

\begin{tabular}{|c|c|c|}
\hline & $\begin{array}{l}\text { Dairy and field crops } \\
\text { group }\end{array}$ & $\begin{array}{l}\text { Orchard and vineyard } \\
\text { group }\end{array}$ \\
\hline Range in charges: & \multirow{4}{*}{$\begin{array}{r}\$ 36.53 \\
0 \\
\$ 5.05\end{array}$} & \multirow{4}{*}{$\begin{array}{r}\$ 15.75 \\
0 \\
\$ 4.87\end{array}$} \\
\hline High...................... & & \\
\hline Low........... & & \\
\hline Average......... & & \\
\hline Most frequent charges...... & $\$ 1.00-\$ 10.00$ & $\$ 5.00-\$ 10.00$ \\
\hline
\end{tabular}

The average miscellaneous expenses incurred per animal per year amounted to $\$ 5.01$.

\section{Credits.}

Credits are made up of the net value of colts at weaning age and the value of manure produced. Few farm operators reported credits. Apparently the manure output is not fully appreciated. Of the 140 dairy and field crop farms, only 8 reported credits, these eight ranging from 75 cents to $\$ 30$, and averaging for the eight $\$ 9.37$ per horse. Only one of the 47 orchard and vineyard group report credit of $\$ 50$. Because of the possibility of an average being misleading, since the reports are inadequate, credits are ignored in the calculations of costs hereinafter set forth.

\section{Total Net Cost of Work Horses per Head.}

Bringing together the various items set forth above results in a figure indicating the average net cost for work horses per animal per year. The findings are as follows: 
TABLE 14

Total Net Cost Per Head Per Year-Averages

\begin{tabular}{|c|c|c|}
\hline & $\begin{array}{l}\text { Dairy and field crops } \\
\text { group }\end{array}$ & $\begin{array}{l}\text { Orchard and vineyard } \\
\text { group }\end{array}$ \\
\hline 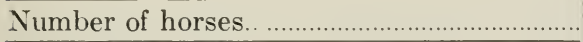 & 665 & 147 \\
\hline 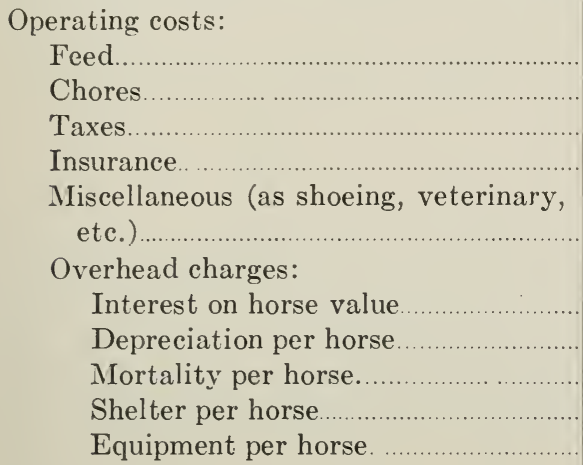 & $\begin{array}{r}\$ 89.80 \\
22.52 \\
1.42 \\
\text { Nominal } \\
\\
5.05 \\
\\
672 \\
12.30 \\
7.39 \\
11.27 \\
7.11\end{array}$ & $\begin{array}{r}\$ 118.61 \\
43.55 \\
2.21 \\
\text { Nominal } \\
\\
4.87 \\
\\
6.17 \\
13.13 \\
\text { Nominal } \\
17.25 \\
5.35\end{array}$ \\
\hline $\begin{array}{l}\text { Gross cost per year } \\
\text { Credits }\end{array}$ & $\begin{array}{l}\$ 163.58 \\
\text { Nominal }\end{array}$ & $\begin{array}{l}\$ 211.14 \\
\text { Nominal }\end{array}$ \\
\hline
\end{tabular}

The cost per horse per year amounted to an average of $\$ 163.58$ for the animals in the dairy and field crops group, and an average of $\$ 211.14$ for the orchard and vineyard group.

Based on all horses included in this study the average net cost per horse per year amounted to $\$ 172.19$.

Hours of Work per Year.

A wide variation exists in the amount that horses are used by different operators. This is shown in the following table:

TABLE 15

Hours of Use Per HeAd PER YeAR

\begin{tabular}{|c|c|c|c|c|}
\hline & \multicolumn{2}{|c|}{ Dairy and field crops group } & \multicolumn{2}{|c|}{ Orchard and vineyard grour } \\
\hline 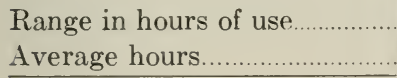 & \multicolumn{2}{|c|}{$\begin{array}{c}454-3382 \\
1672\end{array}$} & \multicolumn{2}{|c|}{$\begin{array}{c}468-2700 \\
1441\end{array}$} \\
\hline Classification by number of hours & $\begin{array}{l}\text { Number of } \\
\text { farms }\end{array}$ & $\begin{array}{l}\text { Percentage } \\
\text { of group }\end{array}$ & $\begin{array}{c}\text { Number of } \\
\text { farms }\end{array}$ & $\begin{array}{l}\text { Percentage } \\
\text { of group }\end{array}$ \\
\hline Less than $\tilde{500}$ & 2 & $1 \%$ & $\ldots \ldots$ & $\ldots$ \\
\hline 500 to $1000 \ldots$ & 30 & 21 & 1 & $2 \%$ \\
\hline 1000 to 1500 & 40 & 28 & 6 & 13 \\
\hline 1500 to 2000 .. & 22 & 16 & 12 & 25 \\
\hline 2000 to 2500 & 33 & 24 & 24 & 51 \\
\hline \multirow[t]{2}{*}{2500 and over. } & 13 & 10 & 4 & 9 \\
\hline & 140 & 100 & 47 & 100 \\
\hline
\end{tabular}


The average annual number of hours of use per horse was 1527 hours.

The number of hours as set forth above is only approximate. No accurate records were available to show the number of hours that these work horses were actually in use. Operators were, however, able to state with a fair degree of certainty the periods when the teams were employed. These data, therefore, though valuable for comparable purposes are not absolute criteria of actual productive use.

\section{Cost per Hour for Horse Labor.}

The cost per hour of use varies with each individual ranch, because methods of feeding, costs of feed, amount of chores, wages paid for chores, investment in horses, barns, and equipment are variable, and to these variations is also to be added the difference in amount of work done on different farms. The following table shows the variation in costs for farms in each group:

\section{TABLE 16}

Showing Variation in Costs per Hour for Horse Labor on Different Farms When All Factors are Taken Into Account

\begin{tabular}{|c|c|c|}
\hline & $\begin{array}{l}\text { Dairy and field crops } \\
\text { group }\end{array}$ & $\begin{array}{l}\text { Orchard and vineyard } \\
\text { group }\end{array}$ \\
\hline $\begin{array}{l}\text { Range for group } \\
\text { Average }\end{array}$ & $\begin{array}{l}4.9-40.7 \mathrm{c} \\
10.06 \mathrm{c}\end{array}$ & $\begin{array}{l}7.2-32.3 \mathrm{c} \\
14.42 \mathrm{c}\end{array}$ \\
\hline $\begin{array}{l}\text { Variation of costs: } \\
4.9 \text { to } 10 \mathrm{c} \text { per horse hour....... } \\
10 \text { to } 15 \mathrm{c} \text { per horse hour......... } \\
15 \text { to } 20 \mathrm{c} \text { per horse hour } \\
20 \text { to } 25 \mathrm{c} \text { per horse hour......... } \\
25 \mathrm{c} \text { and over per horse hour.. }\end{array}$ & 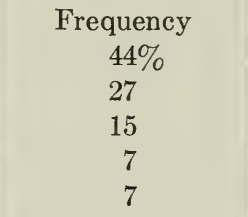 & $\begin{array}{l}\text { Frequency } \\
\qquad \begin{array}{c}13 \% \\
31 \\
30 \\
20 \\
6\end{array}\end{array}$ \\
\hline
\end{tabular}

Average yearly cost for all horses amounted to 11.03 cents per hour for actual time worked.

The cost per hour is principally affected by the amount of productive and profitable work that an animal does during the year. Feed costs, chores and shoeing are reduced somewhat when horses are not working, but charges for taxes, interest, depreciation, mortality, shelter, and equipment are fixed annual charges. Savings when horses are idle are at best small in connection with necessary outlay for feed, chores, and miscellaneous items. 
The importance of this point is shown in the following table, using data from table 14 of total net cost per head per year averaged for all horses.

TABLE 17

Cost Per Hour for Horse Labor Based on Varying Amount of Use

Cost per hour for time worked

Number of hours of work per year (Based on average cost for all horses 750

1250 included in study)

1750

22.9 cents

13.7 cents

9.8 cents

2250

7.7 cents

Relative Importance of Cost Items.

A study of the relative importance of the various elements of costs, which together constitute the annual cost per head for keeping work horses, serves to indicate the items deserving special attention in considering ways of economizing in horse labor. The findings for the 812 horses covered by this study are set forth in table 18 .

\section{TABLE 18}

Percentage of Each Factor Entering Into the Gross Annual Cost of KeEping Work Horses-Average for 812 Horses

\begin{tabular}{|c|c|c|}
\hline & $\begin{array}{l}\text { Dairy and field crops } \\
\text { group }\end{array}$ & $\begin{array}{l}\text { Orchard and vineyard } \\
\text { group }\end{array}$ \\
\hline Feed.. & \multirow{8}{*}{$\begin{array}{c}55.1 \% \\
13.8 \\
3.9 \\
4.1 \\
7.5 \\
4.5 \\
6.8 \\
4.3\end{array}$} & \multirow{8}{*}{$\begin{array}{c}56.4 \% \\
20.6 \\
3.3 \\
2.9 \\
6.2 \\
\ldots \ldots . \\
8.1 \\
2.5\end{array}$} \\
\hline 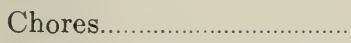 & & \\
\hline Taxes and miscellaneous... & & \\
\hline Interest & & \\
\hline Depreciation... & & \\
\hline Mortality......... & & \\
\hline Shelter.......... & & \\
\hline \multirow[t]{2}{*}{ Equipment... } & & \\
\hline & 100.0 & 100.0 \\
\hline
\end{tabular}

The significance of the data presented above is that feed and chores together constitute from two-thirds to three-fourths of the total cost of keeping work horses. Fortunately, attention to proper and economical feeding and efficient use of labor is within control of each individual operator. 
Items such as taxes, interest, shelter, and equipment are largely fixed. Study of the data shows, however, that material economies can be obtained by keeping contemplated investments in horses, shelter, and equipment at as low a level as is consistent with quality.

The depreciation and mortality factors are to some extent under the control of the operator, and lengthening the productive life of a work horse and reducing mortality will have its effect upon annual costs of horse labor.

\section{UNIT FACTORS}

Costs in dollars are of only passing interest since current figures are not likely to remain stationary. The price of feeds-the largest single item entering into these costs-is particularly prone to vary from year to year or during a single season, and in different localities. Unit factors, meaning basic items measured whenever possible in terms of time and quantity, provide a formula for future calculations which will apply as long as present procedure in handling horses is followed.

Unit factors for workhorses, drawn from the data collected from the two groups comprising these 187 farms, is summarized in the following table. Data are given in terms of money only when no other measure is available.

TABLE 19

Unit Factors Involved in the Cost of Kening Work Horses, Per Animal PER YEAR

\begin{tabular}{|c|c|c|c|}
\hline Cost of & $\begin{array}{l}\text { Dairy and field } \\
\text { crops group }\end{array}$ & $\begin{array}{l}\text { Orchard and } \\
\text { vineyard group }\end{array}$ & All farms \\
\hline 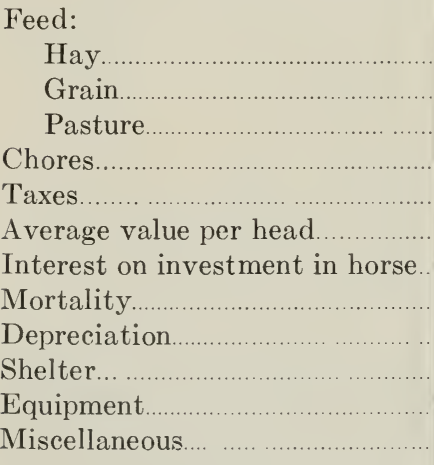 & $\begin{array}{c}5 \text { tons } \\
274 \text { lbs. } \\
2.5 \text { mos. } \\
12 \text { minutes } \\
\$ 1.42 \\
\$ 111.94 \\
\$ 6.72 \\
6.6 \% \\
8.55 \% \\
\$ 11.27 \\
\$ 7.11 \\
\$ 5.05\end{array}$ & $\begin{array}{c}6 \text { tons } \\
435 \text { lbs. } \\
1.5 \text { mos. } \\
24 \text { minutes } \\
\$ 2.21 \\
\$ 102.79 \\
\$ 6.17 \\
\text { Nominal } \\
6.97 \% \\
\$ 17.25 \\
\$ 5.35 \\
\$ 4.87\end{array}$ & $\begin{array}{c}5.4 \text { tons } \\
308 \text { lbs. } \\
2 \text { mos. } \\
15 \text { minutes } \\
\$ 1.62 \\
\$ 107.33 \\
\$ 6.44 \\
5.1 \% \\
8.15 \% \\
\$ 12.77 \\
\$ 6.66 \\
\$ 5.01\end{array}$ \\
\hline Credits... & Nominal & Nominal & Nominal \\
\hline
\end{tabular}




\section{EFFECT OF COST OF FEED}

The average annual feed bill per horse amounted to $\$ 95.75$, the costs on individual farms ranging from $\$ 23.82$ to $\$ 295$. Low costs can be attributed to pasturing horses when idle or to special conditions making for cheap feed. The high costs are largely due to wastage of feed or to excessive prices paid for feed. Of the ranches studied in the dairy and field crops group, 23 reported annual feed costs amounting to over $\$ 125$ per horse so that the average feed cost of these was 7.8 cents per work hour against a group average figure of 5.6 cents per hour.

The importance of keeping down feed costs is shown by the following table. Here are presented the actual costs on five ranches which had the highest annual feed cost, in comparison with average costs of all ranches in the dairy and field crop groups- $\$ 89.80$.

TABLE 20

EFfect of Feed Costs UpoN Cost PeR Hour of Work

\begin{tabular}{|c|c|c|c|c|c|c|c|c|}
\hline \multirow{3}{*}{$\begin{array}{c}\text { Ranch } \\
\text { No. }\end{array}$} & \multirow{3}{*}{$\begin{array}{l}\text { Number } \\
\text { of hours } \\
\text { worked }\end{array}$} & \multicolumn{3}{|c|}{ Actual } & \multicolumn{3}{|c|}{ Under average feed cost } & \multirow{3}{*}{$\begin{array}{l}\text { Saving } \\
\text { per hour } \\
\text { of work }\end{array}$} \\
\hline & & \multicolumn{2}{|c|}{ Feed cost } & \multirow{2}{*}{$\begin{array}{l}\text { Total } \\
\text { cost per } \\
\text { hour of } \\
\text { work }\end{array}$} & \multicolumn{2}{|c|}{ Feed cost } & \multirow{2}{*}{$\begin{array}{l}\text { Total } \\
\text { cost per } \\
\text { hour of } \\
\text { work }\end{array}$} & \\
\hline & & Annual & Per hour & & Annual & Per hour & & \\
\hline 1 & 1799 & $\$ 295.00$ & $16.4 \mathrm{c}$ & $22.2 \mathrm{c}$ & $\$ 92.09$ & $5.1 \mathrm{c}$ & $10.9 \mathrm{c}$ & $11.3 \mathrm{c}$ \\
\hline 2 & 1500 & 178.20 & 11.9 & 16.4 & 92.09 & 6.1 & 10.6 & 5.8 \\
\hline 3 & 2660 & 176.00 & 6.6 & 10.6 & 92.09 & 3.5 & 7.5 & 3.1 \\
\hline 4 & 2808 & 173.50 & 6.2 & 11.4 & 92.09 & 3.3 & 8.5 & 2.9 \\
\hline 5 & 832 & 168.00 & 20.2 & 25.3 & 92.09 & 11.1 & 16.2 & 9.1 \\
\hline
\end{tabular}

This table serves to illustrate another fact, namely, that the fewer hours per year that the horse works, the more important it is to keep down the feed cost. Farms Nos. 4 and 5 have approximately the same annual feed cost, yet farm No. 4, where the horses work an average of 2808 hours, would have made a saving of only 2.9 cents per hour had the feed bill been that of the average ranch, whereas on farm No. 5 , where the horses worked only 832 hours, the saving would have been 9.1 cents per hour. 


\section{SUMMARY}

A study of the cost of keeping 812 work horses on 187 California farms indicated that under the conditions existing at the time (for year 1922) the average cost per animal per year amounted to $\$ 172.19$.

The average cost of maintaining horses on orchard and vineyard, farms was found to be higher than on dairy and field crop farms, being $\$ 211.14$ for the former group and $\$ 163.58$ for the latter group. Of the various items making up the cost of maintaining work horses, feed and chores are the two largest single costs. These amounted to $\$ 112.32$ (or $68.9 \%$ ) for the dairy and field crop group, $\$ 162.16$ (or $77 \%$ ) for the orchard and vineyard group.

The majority of operators fed hay only, at an average rate of 6 tons per head per year. When grain was fed the amount averaged $780 \mathrm{lbs}$., with a reduction of but one-tenth of a ton of hay. An average of five months of pasture replaced 1.7 tons of hay.

Prices for the period of study mostly ranged between $\$ 15$ to $\$ 18$ per ton of hay, $\$ 2.50$ to $\$ 3$ per horse-month for pasture, $\$ 1.75$ per 100 pounds for grain, 30.9 cents per hour for choring, $\$ 1.62$ for taxes, $\$ 5.01$ for shoeing, veterinary and similar miscellaneous minor items, $\$ 12.77$ for shelter and $\$ 6.66$ for use of equipment.

Credits (for colts and manure) were relatively small. The value of the manure is apparently not appreciated by horse owners.

Mortality averaged 5.1 per cent, depreciation 8.14 per cent.

The number of hours that horses are used per year is the greatest single factor affecting cost per hour. Yearly use was found to range from 454 to 3382 hours per horse, with a general average of 1527 hours,

The average cost per horse-hour for time actually worked amounted to 11.03 cents, or approximately $\$ 1$ per day for a 9-hour day.

\section{ACKNOWLEDGMENT}

In addition to the data collected by fieldmen in connection with a study of the cost of producing milk on California dairy farms, ${ }^{*} 47$ records, collected by Mr. W. L. Jackson, and constituting the orchard and vineyard group have been used. Mr. L. E. Haseltine gave substantial assistance in connection with compiling, summarizing, and analyzing the various records.

* Published in University of California Experiment Station Bulletin 372. 


\section{NANNEson, Ludvig}

1916. Räkenskapresultat från svenska jordbruk. 1. Bokföringsåret 1914-1915. Meddelanden från Kungl. Lantbruksstyrelsen 201 (5 år 1916), 1-85. Aktiebolaget Skånsa Centraltryckeriet. Lund, Sweden.

1918. Ibid. 2 Bokföringsåret 1915-1916 . . 206 (5 år 1917), 1-86. Aktiebolaget Skånska Centraltryckeriet. Lund, Sweden.

1919. Ibid. 3 Bokföringsåret 1916-1917 . . 217 (3 år 1919), 1-85. Röhr's Boktryckeri. Malmö, Sweden.

1920. Ibid. 4 Bokföringsåret 1917-1918 . . . 224 (5 år 1920), 1-71. Röhr's Boktryckeri. Malmö, Sweden.

1921. Ibid. 5 Bokföringsåret 1918-1919 . . . 234 (5 år 1921), 1-94. Förlagsaktiebolagets i Malmö Boktryckeri. Malmö, Sweden.

1922. Ibid. 6 Bokföringsåret 1919-1920 . . . 241 (7 år 1922), 1-111. Röhr's Boktryckeri. Malmö, Sweden.

1923. Ibid. 7 Bokföringsåret 1920-1921 . . 246 (5 år 1923), 1-111. Röhr's Boktryckerei. Malmö, Sweden.

1924. Ibid. 8 Bokföringsåret 1921-1922 . . . 251 (4 år 1924), 1-82. Röhr's Boktryckeri. Malmö, Sweden.

1924. Jordbruksekonomi, 1-135. C. E. Fritzes Bokförlags Aktiebolag. Stockholm, Sweden.

OvergaARD, J. C.

1918. Unders $\emptyset$ gelser over Landbrugets Driftsforhold 1 Nogle Regnskabsresultater fra danske Landbrug i Aaret 1916-1917. 1-47. Konrad Jørgensens Bogtrykkeri. Kolding, Denmark.

Pedersen, M.

1916. Landbrugets Rentabilitet. 1-308. Copenhagen.

Sunila, J. E.

1916. Undersökning af landthushållningens i Finland rentabilitet 1 . Räkenskapsåret 1913-1914. Landtbruksstyrelsens Meddelanden 109; Landtbruksekonomiska Afdelningens Publikation 5: 1-214. Kejserliga Senatens Tryckeri. Helsingfors.

1918. Ibid. 3 . . 1914-1915. Lantbruksstyrelsens Meddelanden 118; Lantbruksekonomiska Avdelningens Publikation 8: 1-205. Finlands Senats Tryckeri. Helsingfors.

1919. Ibid. 4 . . 1915-1916 ... 128 . . 11: 1-224. Statsrådets Tryckeri. Helsingfors.

1920. Ibid. $5 \ldots$. 1916-1917 . . 133 . . 12: 1-211. Statsrådets Tryckeri. Helsingfors.

1922. Ibid. $8 \ldots$. 1919-1920 . . 142 . 15: 1-50. Statsrådets Tryckeri. Helsingfors.

UdValget For det LandǿJonomiske Driftsbureau (Danmark)

1916. Plan og Regler for Landbrugs-Regnskabsføringen. Konrad Jørgensens Bogtrykkeri. Kolding. 
